\title{
7 Tew Heathenry between past and present. The case of Ásatrúfélagið and Samfundet Forn Sed
}

\section{Irina Manea}

University of Bucharest, E-mail: irinamaria.manea@yahoo.se

https://orcid.org/0000-0001-7959-710X

\begin{abstract}
As a variant of alternative spirituality derived from postmodern fluidity and fragmentation of large narratives, Nordic Heathenry has gone through a revival for the past decades. Due to the common ground of potentially völkish/ethnicist views shared by far-right milieus, it has been confronted with the risk of the extremist framework dominating the reception of Norse symbols and myths. While many strains of heathenry might present similarities in their neo-romantic nativist revival, some have been attempting to focus on a heritage discourse that can become acceptable and normalized in society, reflecting an open and inclusive attitude. The Asatru Association in Iceland and The Old Way in Sweden, through their public message and stated mission, underline the need for the freedom to reinvent myth and ritual while remaining anchored in the present, thus distancing themselves from other cultural appropriations and proclaiming their own role in society. The very flexible view on myth and ritual constitutes a defining aspect for the identity of these movements.
\end{abstract}

\section{Rezumat}

Ca variantă de spiritualitate alternativă provenită din fluiditatea postmodernă şi fragmentarea marilor naraţiuni, Păgânismul nordic a trecut printr-o renaştere în ultimele decenii. Din cauza terenului comun de perspective potenţial etnicizante împărtăşite şi de gruoările de extremă dreaptă, s-a confruntat cu riscul unei abordări extremiste care să ajungă să domine receptarea simbolurilor şi miturilor nordice. În vreme ce multe direcții de neopăgânism pot afişa similarităţi în renaşterea nativismului romantic, unele au incercat să se axeze pe un discurs despre trecut care să fie acceptabil şi normalizat în societate, reflectând o atitudine mai deschisă şi incluzivă. Asociaţia Asatru din Islanda şi Vechea Cutumă din Suedia, prin mesajele lor publice şi scopul declarat, subliniază nevoia unei libertăți în reinventarea miturilor şi ritualurilor, rămânând ancorate în prezent, prin urmare îndepărtându-se de alte aproprieri culturale şi definindu-şi rolul în societate. Viziunea foarte flexibilă asupra mitului şi ritualului reprezintă un aspect definitoriu pentru identitatea acestor mişcări.

Keywords: heathen, heritage, Norse myth, identity, spirituality

CC BY-SA License (https://creativecommons.org/licenses/by-sa/2.0)

This paper has been presented at the Twelve International Conference on Baltic and Nordic Studies in Romania: ReThinking multiculturalism, multilingualism and cultural diplomacy in Scandinavia and the Baltic Sea Region, hosted by the Romanian Association for Baltic and Nordic Studies, May 27-28, 2021. 
Much research done in the early 2000s into Neopagan or Heathen movements, more exactly Asatru or the modern worship of the deities of Northern Europe, has been focused disproportionately on the link to white nationalism or national socialism vividly portraying the racist fringe especially in the USA ${ }^{1}$ and subsequently influencing the view on Asatru as a whole, ignoring the great variety inside the new religious phenomenon. Gradually, research tended to a more descriptive and contextualized view, within a larger matrix of religious development or identity politics. ${ }^{2}$ The trend to turn back to native religions is not limited to European Paganism and there have been attempts to categorize the strains of Heathenry into traditional vs. eclectic ${ }^{3}$, genealogical, race-ideological vs. cultural ${ }^{4}$ or racist vs. a-racist.

These movements, regardless of how we classify them, have been interpreted as one means to react to the present in the form of a neoromanticisation of the premodern. Rather than suffering from our estrangement and selfhood crises in an ever-changing world, the ancients are perceived as connected to nature, themselves and the sacred. The contemporary quest for wisdom, primordial oneness and a divorce from institutionalised religion and culture or authority has led us on the path to occulture, New Age, Wicca, esotericism or Heathenry. In the case of the latter, a manifestation of personal worship intersects with a rediscovery and creative reinvention of heritage and the distant past, which might have as an effect a reenchantment but without losing grip of the present. The term 'reconstructed religion' which is frequently used to describe heathen activity, seems far-fetched since there are too few elements to hold on to and, as we shall see in the study cases, innovation in thought and ritual are praised within the framework of Asatru communities. As a more

\footnotetext{
${ }^{1}$ For example Matthias Gardell, Gods of the Blood (Durham: Duke University Press Books, 2003)

2 Such as Jennifer Snook, American heathens: the politics of identity in a Pagan religious movement: a sociological ethnography of American Asatru (Pennsylvania: Temple University Press, 2015)

${ }^{3}$ Michael Strmiska (ed.), Modern Paganism in World Cultures (Santa Barbara: ABC CLIO, 2005)

${ }^{4}$ Frederik Gregorius, Modern Asatru. Att konstruera etnisk och kulturell identitet (Lunds universitet: Media-Tryck, 2009)
} 
comprehensive and useful paradigm we resort to term "art-religion" meaning discourses on myth and religion where aesthetics contribute to shaping faith and ritual. The term is not without its share of ambiguous connotation because of the echo of the conservative revolution and völkisch underpinnings, yet here we are mainly referring to the loose concept of Nordic religion, open to be enriched by its sympathizers. For two (declaratively) non-racist groups from Iceland and Sweden we will briefly analyse them from the point of view of the relationship past-present they depict and what self-image and messages they promote, particularly on their homepages.

For a lot of Heathens Iceland surely represents a place to look up to, since it has the most direct connection to the medieval literary tradition of the sagas and Eddas, considered to gather a lot of material from preChristian times. The fact that the Icelandic heathen community, the Ásatrúarfélagið, has been formally recognized as a religion also contributes to this increase in popularity. However, Icelandic Heathenry only represents one strain of this vast movement and claims of authenticity characterize every one of them, as Icelandic sources might not be regarded by all to be relevant, who might for example prefer older, archaeological sources to cling to. ${ }^{6}$

In fact, Sveinbjörn Beinteinsson, the founder of the Icelandic Asatru community in 1972 was aware of the delicate problem of authenticity and the limited possibility to employ historical sources as a means of religious revival, stating that one cannot have preserved the same faith and life as before and that these need to be adapted to our age: "I don't want to turn back time. I have to live my life in the present"7. His understanding of Norse religion seems to be vaguely spiritual, creative and rather oriented to a lived experience than a reconstruction of the past. In the same interview he

\footnotetext{
${ }^{5}$ Stefanie von Schnurbein, Norse Revival. Transformations of Germanic Neopaganism (Boston: Brill, 2016)

${ }^{6}$ Julia Zernack, "Germanische Altertumskunde, Skandinavistik und vöklische Religiosität" in Völkische Religiosität und Krisen der Moderne. Entwürfe "arteigener" Glaubenssysteme seit der Jahrhundertwende, ed. J. Ulbricht, S. von Schnurbein (Würzburg, 2001), 228-234

${ }^{7}$ Gisela Graichen, Die neuen Hexen (Goldmann Wilhelm GmbH, 1999), 264
} 
connects it to nature, beings from folklore or spirits of the dead with whom people have a more personal tie than the cold holiness of Christianity. Anyone can pray to the old gods as they wish, as there is no dogma and their functions may vary accordingly.

In the following we will have a look at how this new religion developed and how it is rooted in the contemporary world, in spite of or because of its attempt to recover the past. To briefly contextualize the Icelandic case, we should mention the process of colonisation that took place beginning with the end of the $9^{\text {th }}$ century, when a free-state was formed, very different than anything else experienced in Europe at the respective time. The polity which knew no kings or magnates based itself on collection of laws and on networks among free men, farmers and chieftains (goðar) with limited authority. Besides the local gatherings, there used to be a general gathering (Althing) held in the tenth week of summer, when legal suits were carried out and the law speaker (lögsögumaðr) recited a third of the laws. The date is now used by the Asatruar as a feast of sacrifice (pingblót), although it rather had legal content back then. In 956 Iceland had 48 goðar, who were supposed to choose the courts and lead the trials, acting as the influential and prestige-seeking members of the community. The Book of Settlements (Landnámabók) also alludes to their religious function, caring for the temples and then churches ${ }^{8}$ although their exact attributes as priests, or keepers of the sacred order, are somewhat unclear. After conversion they became involved with building churches and maintaining them as private property. After a series of missions, most intensely led by Norway's proselyte king Olav Tryggvason, Christianity is accepted around the year 1000, with the consequence that "the Church expanded the cultural horizon by introducing ideas from the Latin West" ${ }^{\prime 9}$ while not supplanting Iceland's tradition of secular governance in the first centuries and not forming a distinct caste. Njáls saga, although not historical and probably exaggerated, however offers a lively account of the tense state of affairs during conversion. It tells of the preacher Thangbrand's aggressive methods including killings, his

\footnotetext{
${ }^{8}$ The Book of Settlements, tr. H. Palsson, Book 4, chapter 7 (University of Manitoba Press, 2007) ${ }^{9}$ Jesse Byock, Viking age Iceland (London: Penguin Books, 2001), 297
} 
unsuccessful return to Norway and king Olaf's retaliation by closing ports endangering Iceland's foreign relationships. The antagonistic groups on the island raising the issue of establishing different courts depending on faith were heading towards a skirmish that was skilfully avoided at the Althing, where a typical scenario occurred, with mediators and arbitration. Drawing attention that a division of law would mean a division of peace, law speaker Thorgeir decided for Christianisation but without giving up heathen customs altogether, sacrifices being accepted in private. A skillful compromise avoided a sharp break with the past, and "we may guess that they feared social upheaval more than they disliked religious change"10. Perhaps this could be considered a historical reason why someone in Iceland now would only consider themselves Christian only formally.

Fast forward to the 70s, Beinteinsson's initiative to recover ancient beliefs were not a reaction to Christianity in general but to new sectarian movements which he deemed unnecessary since there was already a spiritual alternative to explore. With only a few members at the time, Ásatrúarfélagið gained state recognition in 1973, counting today over 4500 members and growing ${ }^{11}$. The legal recognition was possible thanks to the constitution of 1874, which on the one hand confirmed the position of the evangelical Church but on the other hand allowed for the founding of other religious groups, as specified in article 63, which specifies that anyone can practice their religion following their convictions, as long as it does not disturb public order and complies with good norms ${ }^{12}$, besides providing proof of activity and stability. Once recognized by the Ministry of Internal Affairs, the religious community has the right to organise ceremonies like marriage or burial. The Asatru group prepares not only blót celebrations, which are open for the general public, but also rituals of passage, divided among the goðar who receive training to perform them. The rites take place in nature, in historically resounding spots such as pingvellir or Snæfellsjökull, to compensate for the lack of sources regarding the rituals

\footnotetext{
${ }^{10}$ Byock, 301

${ }^{11}$ asatru.is/felagafjoldi, accessed 23.04.2020

12 althingi.is/lagar, accessed 23.04.2020
} 
themselves. This compensation is also realised by resorting to some of the literary sources and arranging them to fit the context. Nafngjöf, the namegiving, like the Christian baptism, introduces the child to its community, on which occasion the goði speaks verses from the Eddic collection, Völuspá and Hávamál for instance, with the statement that every newborn symbolises the eternal cycle of life. A relevant argument for the novelty and creative aspect of Asatru, which combines art with religion to induce a sense of the sacred, is the addition of a poem written by S. Beinteinsson: Megi mannheill/ nafni fylgja /styrki pig guðir /og góðar vættir /álfar og dísir / og allt sem lifir. /gróður jarðar /og geisli sólar ${ }^{13}$. - may good luck / follow the name / may the gods / and good spirits / alfar and disir / and everything that lives strengthen you / and the plants of the earth / and rays of the sun. Other specific elements include nine candles burning in a circle, reminding of the nine mythological realms, a dedication of the place, as well as the gift of a runic necklace and sharing a horn of mead. The sense of community plays a decisive part: “Hvort sem við erum foreldrar, vinir eða ættingjar pá tökum við pátt í að ákvarða ævi fólksins í kringum okkur og fléttumst inn í vefi skapanornanna priggja. Раð er pess virði fyrir okkur öll að ígrunda hvernig við höfum áhrif á hvert annað." - whether we are parents, friends or relatives we are involved in influencing the lives of people around us and we are woven in the web created by the three Norns. For all of us it is worth reflecting on how we affect each other.

For weddings which are performed quite often, there is no textbook either. Materials used for the ceremony come from innovation and artistic impulse mostly, since neither Eddas nor earlier sources provide information on that account, possibly because they would have been redundant for their public. Goði Jormundur Ingi Hansen offered some examples: the marriage of Sigurdrífa and Sigurd from Sigrdrífumál, the marriage of Odin to Gunnlöth in Hávámal, the marriage of Freyr and Gerth in Skírnismál. The ceremony happens outside and there should be a tree, a spring and a ring of

\footnotetext{
${ }^{13}$ asatru.is/nafngjof, accessed 24.04.2021
} 
fire $^{14}$. Again we can notice the reverence towards nature and the importance of the setting recalling the world tree Yggdrassil or the well of Urd. The bride and groom state their intention to fulfill their responsibility, after the goði's readings from the Eddic poems and the invocation of the goddesses Frigg and Freyja linked to marriage and fertility or Vár, god of pacts ${ }^{15}$. The drinking horn, libations and placing of hands over an arm-band, a symbol of oath in the Pagan North, also belong to the ritual, but participants are free to contribute. We can thus notice that heritage is reinterpreted and even invented in order to fit these occasions. According to Hilmar Örn Hilmarsson, the current holder of the office of general goði (allherjargoði), “hver athöfn er einstök pví pær eru ætíð sniðnar að óskum og áherslum brúðhjónanna sjálfra. Stundum felst pað í pví að fleiri goð eru kölluð fram peim til fulltingis, stundum fær tónlist meira vægi og stundum koma vinir eða ættingjar að athöfninni með upplestri eða persónulegu framlagi"16 every ceremony is unique because it is tailored to the wishes and interests of the bride and groom. Sometimes it means that more gods are invoked to help them, and sometimes friends or relatives come to the ceremony with a reading or personal contribution. The funerary ritual shares the same personal note, with readings from the Edda, artistic performances, meditation, marking of the coffin with sun-crosses or wishing the deceased a good afterlife regardless of how they imagined it. Once more, we can notice the flexibility of the approach and the adaptation to a contemporary context, with Ibn Fadlan's description and the archaeological finds of funerary boats being left in the past, although there are voices that would prefer a return to a more historical option like a mound or at least one that is not so heavily dependant on Christian custom ${ }^{17}$. In order to insure compliance with the wishes of the relatives, one can download a form on the homepage with all

\footnotetext{
${ }^{14}$ Michael Strmiska, "Ásatrú in Iceland. The rebirth of Nordic Paganism?", in Nova Religio, The Journal of Alternative and Emergent Religions 4:1 (University of California Press, 2000), 119

15 Ibid., 120.

${ }^{16} \mathrm{mbl}$.is/greinasafn/grein/1198406, accessed 24.04.2021

${ }_{17}$ Silke Schurack, Burial practice in contemporary Iceland. Tradition and conflict (Haskoli Islands: 2014), 29
} 
the details, including the option for cremation or interration, what the grave should look like or even the garments of the priest at the funeral.

Besides the private events aforementioned, the sacrifice (blót) is more representative of Ásatrú and meant to offer the deity more power. A place is dedicated with the following words: “Lýsi ég staðarhelgi, lýsi ég mannhelgi, lýsi ég blóthelgi. Lýsi ég véböndum, lýsi ég griðum, lýsi ég sáttum."18 - I proclaim a local sanctuary, I proclaim a sanctuary for people, I proclaim a sanctuary for offerings. I proclaim bonds, I proclaim peace, I proclaim reconciliation. Blót means offerings of food, recitations, music, dancing, sharing the drinking horn, making dedications to gods of choice, or other activities meant to enforce the sense of belonging as well as that of common heritage, such as a green banner where people could "paint some symbol or design onto the banner. A wide range of white shapes appeared on the banner ranging from a tree, to human-like figures, a Viking-age ship, and runes [...] when all those in attendance had applied their contributions, the banner was taken down and hurled into the fire as a sacrificial offering which was believed to contain something of each person present."19 Blót occasions include Jólablót for the winter solstice, Sigurblót, victory sacrifice on the first day of summer and also the founding day of the religion, Pingblót for the summer solstice, Veturnáttablót on the first day of winter; yet it is specified that priests can hold their own sacrifices in the respective districts and moreover, anyone can do it, under the condition that they employ as a ritual guide the advice offered in Hávamál: "Veistu hve rísta skal? / Veistu hve ráđa skal?/ Veistu hve fáa skal? / Veistu hve freista skal? / Veistu hve biðja skal? / Veistu hve blóta skal? / Veistu hve senda skal? / Veistu hve sóa skal?" 20 - do you know how to carve / what to do / how much to get / what to try / how to pray / how much to sacrifice / how to send / how to waste?

Based on tentative historical descriptions in the Eyrbyggja saga for example, and archaeological hints that temples might have been mere farmhouses, at least before the interaction with Christianity, a project for a

\footnotetext{
${ }^{18}$ asatru.is/blot, accessed 25.04.2021

${ }^{19}$ Strmiska, 122

${ }^{20}$ asatru.is/blot, accessed 24.04.2021
} 
temple began in 2003 under the leadership of architect Magnus Jennson, who stated that his idea was not quite to imitate a Pagan temple, but rather to suit it for present needs and the plot of land: a building with a shrine and a dome, with a cliff incorporated and a pond and spring flowing inside ${ }^{21}$, thus loyal to the ecologism promoted by the religious group. The temple would have also contained a reception, multipurpose rooms, a kitchen and even a café. Unfortunately unfinished due to financial and technical reasons, the news of the building raised the interest of many Pagan groups all over the world, as well as of the general public. Press titles such as "How Iceland recreated a Viking-age religion" 22 or "Iceland is building its first Nordic paganist temple in 1000 years" 23 increased the phenomenon's popularity while promoting a myth about it, that it represents a reconstruction of ancient tradition.

As we have seen in the beginning, the founder of the society himself had no such pretentious claims. We can uncover more signs of the modernity of this religion except for those already presented in rituals. As we have seen, the Eddic texts are open to subjective interpretation. The main source of ethic inspiration, the Hávamál, contains very down-to-earth, witty, sometimes cunning, other times generous pieces of advice which it shares with other works of wisdom literature. A contemporary touch is that animal sacrifice remains, for instance, out of the question. Then, they are dealing with the very stringent and controversial topics of the day. On the question of homosexual marriage, the official position seems to be a positive one. Multiple times, the chief priest of Ásatrú Hilmar Hilmarsson expressed his tolerance and support for the LGBT community, on which occasion there have been clashes with other foreign heathen groups who wanted to visit the temple. He regards the group's fight for acceptance and marriage of homosexual couples as a "ákveðinn endurómur af íslensku samfélagi" 24 - a definitive echo of Icelandic society. He also points out that the ancient texts

\footnotetext{
${ }^{21}$ Magnus.jennsson.is, accessed 24.04.2021

22 bbc.com/travel/story/20190602-how-iceland-recreated-a-viking-age-religion, accessed 20.04.2021

23 weforum.org/agenda/2018/07/iceland-s-fastest-growing-religion-will-soon-complete-thefirst-temple-to-thor-and-odin-in-1000-years, accessed 20.04.2021

${ }^{24}$ visir.is/g/20151552208d, accessed 21.04.2021
} 
should not be misused to promote values which are no longer valid today and to impose Viking warfare romances. Moreover, in the statement of purpose, the association underlines its desire to raise awareness of local folklore, tradition and religion, yet at the same time "án pess að gera lítið úr öðrum trúarsiðum, gömlum eða nýjum, eða menningu annarra pjóða. Ofstæki eða hatur í garð annarra getur aldrei samrýmst stefnu félagsins" 25 without underestimating other religions, old or new, or the cultures of other peoples. Fanaticism and hatred towards others can never be in harmony with the society's policy. On a formal level at least, the group is attempting to keep at bay potential racialisations or a too strong focus on ethnicity. While their internal code mentions respect for old customs and strong morals, the very vagueness of this formula could create a space for extremist views to manifest. As the attempts of right-wing strains to co-opt Norse symbols continue, Icelandic Heathenry and other organisations counteract the ideological hijacking, yet the effect remains unclear, as well as the answer to the question as to whether Heathenry can be saved from political instrumentation in order to express extremist views. Noticing the division among Danish heathens and how some of them had went down the path of Stephen McNallen's teaching about the connection between faith and blood, Hilmarsson underlined the necessity to constantly set boundaries. ${ }^{26}$ The founder of the Viking Brotherhood and then the Asatru Free Assembly developed an admiration for the heroism depicted in popular media and went into the direction of innate ties between "Germanic" peoples and Heathenry. This view led to splits inside the group and probably the dissolution of the Asatru Free Assembly. ${ }^{27}$ On the other hand, in Iceland the relationship between heathen members of the society and ethnicist or racial ideas hasn't had much territory of exploration either, because of the simple fact that the country is traditionally very homogenous. Hidden prejudices towards the small but growing numbers of non-Icelanders haven't quite been a topic of research and in the future it would be interesting to watch

\footnotetext{
${ }^{25}$ asatru.is/felagsstarf, accessed 21.04.2021

${ }^{26}$ visir.is/g/2014708289971/nynasistar-misnota-nafn-asatruarfelagsins

${ }^{27}$ Von Schnurbein, 59
} 
how and if the attitude of the Ásatrúfelagið changes, if members adhere to the established tolerant and liberal principles or if there are divisions between a liberal and a more nationalistic strain following the continuous evolution of societal, demographic and mental structures both globally and locally.

While the organisation promotes itself as very open, a-racist and inclusive, the Icelandic Asatru organisation had its share of controversies at its dawn, revolving around the support of the group Nýalssina, which combined spiritist, nationalist and pseudo-scientific ideas. The Nordic gods would have been "denizens of remote stars who had supposedly reached a higher level of consciousness." ${ }^{28}$ Attempts in the 70s to infuse the movement with overt right-wing stances would end up refuted, and in 1982 the Norrænt Mankyn (Nordic race) group was founded, gathering antiimmigrant and pro-life voices. At least on a level of surface, S. Beinteinsson's work with rituals and membership, as well as the subsequent allsherjargóðar, has focused more on the celebration of folklore and old literature and less on the ethnicist aspects. Furthermore, as Norse myth and texts form part of Icelandic identity in general and are promoted as fundamental heritage since early years in schools, its preservation might constitute reason enough to join the organisation. The spiritual identity can also be framed, but with a considerable amount of imagination.

On the question of the organisation being nationalistic or not, judging by membership and sources of revivalism, the answer would be yes, yet it seems to be rather contextual than a statement of purpose. The Asatru Association has become accepted in the mainstream, as suggested by governmental support for various artistic manifestations, for instance a theatrical performance based on the poem Skírnismál, funded by a grant and staged in the basement of the city hall. ${ }^{29}$

Similar organisations making creative use of the past for the sake of a cultural and religious identity have also prevailed in Sweden, and a similar development can be noticed, with controversies and loose networks of

\footnotetext{
${ }^{28}$ Von Schnurbein, 59

${ }^{29}$ Strmiska, 110.
} 
spiritual, a-racist, ethnicist or nationalistic interpretations in the 70s and after the 90 s attempts at more nuanced views, the cultivation of local history and folklore as well as reactions and adaptations to contemporary issues. In matters of conversion, Sweden oscillated for a long time between paganism and Christianity, while rites coexisted. Accounts of more violent encounters survive in stories like Orkneyinga saga or Hervarar saga, and up until the official conversion in the $12^{\text {th }}$ century, old customs were still important in legal processes. Yet as with the other Nordic countries, out of practical reasons Norse myth and ritual were cornered into shadow and remnants survived in folklore. Fast forward a couple of centuries, we will discover a very diverse religious landscape, with only little over $50 \%$ belonging to the Church of Sweden. An option for the many non-affiliated, albeit still from the fringe, points out to Heathenry.

One of the most well established societies, Samfundet Forn Sed, The Old Way, founded in 1994, writes in its statement of purpose that their guidelines stem from a humanistic and democratic point of view, with members standing for tolerance, freedom of religion and the multicultural society, with anyone allowed to join. As we have seen with the Icelandic case, this Swedish society does not hold claims at historical reconstructionism either: "Samfundet syftar till att göra den forna seden till ett levande andligt alternativ för människor i vår egen tid. Vårt syfte är inte att återskapa en forntida religion så som den såg ut för 1000 år sedan och vi ägnar oss inte åt historisk teater. Vi lever seden i nuet, och arbetar ständigt för att utveckla seden som ett andligt uttryck anpassat till dagens samhälle." ${ }^{\prime 3}$ - the association aims at turning old customs into a spiritual alternativ for people nowadays. Our purpose is not to recreate an ancient religion as it looked like 1000 years ago and we do not devote ourselves to historic theatre. We live the custom in the present, and continuously work to develop the custom as a spiritual expression fitting the current society. This is realized by means of ceremonies like the blót, readings, gatherings, a common interest for nature and history. The lack or fragmentariness of sources about Norse religion, many of them documented after the conversion, has allowed for very

\footnotetext{
${ }^{30}$ samfundetfornsed.se/samfundet/om-samfundet-forn-sed, accessed 20.04.2021
} 
personalised and flexible interpretations of religion and ritual, both for the group and the individual. This phenomenon is not limited to Norse Heathenry. Besides offerings, rites of passage are also performed by heathens in Sweden, and at times seið, a shamanic practice to facilitate contact to the gods, and more rarely readings or carvings of runes. ${ }^{31}$ The offerings and their periods vary, and have been influenced by academic writings on the topic, such as Folke Ström's Nordisk Hedendom (1961) or BrittMari Näsström's Blot (2002)32. Again, there are two types of holidays associated with offerings, those usually celebrated and those with a more local or individual touch. The list presented by the group on the homepage is not an exhaustive one, and an individual or small group can also request guidance about how to perform such rituals. Among the most important holidays we encounter julblot (winter solstice), disablot (return of the light, holiday for feminine entities), vårblot (spring equinox, in honour especially of Freyja and the Sun), Majblot (celebration with a procession in honour of fertility gods, including ritual plays), midsommarblot (summer solstice, a mainstream holiday, only different in dedication and local traditions), sensommarblot (late summer, harvest time, prayers to Thor and Siv especially), höstblot (autumn feast, harvest time, gift-giving, sometimes linked to seið), alvablot (celebration of ancestors, alavar as earthly beings linked to them), årsväntan (a new custom, six Thursdays before the winter solstice, lighting pillars, marking the lights with the first runes of the futhark), Torshelgd (Thor's holiday). The blot at the Gamla Uppsala in spring holds a special significance for many members and is entirely created from scratch.

What we can notice from this enumeration is the diversity and importance of choice on what and how to perform and whom to dedicate it to. The link to the old ways is by and large represented by the gods, or at least their portrayal in the historical sources. The blot has as purpose the communication between people and invisible energies symbolised by the gods and the maintenance of this relationship. "Ofta bär vi i blotet fram offer

\footnotetext{
${ }^{31}$ Gardell, 160

${ }^{32}$ Gregorius, 223
} 
av något slag, till exempel mat eller dryck eller något vi har tillverkat. Offret är en symbolisk gåva som vi ger gudarna för att hedra dem och stärka vår våra vänskapsband till dem. Även att hålla blot kan ses som ett offer i sig, då vi ger av vår tid till gudarna." 33 [Often we bring forth an offering of some kind, for example food or drinks or something we have manufactured. The offering is a symbolic gift that we give the gods to honour them and strengthen our bonds of friendship with them. Even holding a blot can be seen as an offering in itself, because then we offer some of our time to the gods]. Thus the society does not aspire to revive pre-Christian religion but above all else to encourage creativity in the approach of blot or other elements. The old customs are actually a modern construct, because empty spaces are being filled with relevant information from a wide variety of sources, ranging from academic writings, popular retellings, magical and metaphoric views, up to inspiration from other new religious trends like the nature-oriented ones, while dismissing habits considered anachronic (live sacrifice or blood sprinkling). Moreover, gatherings on the occasion of blot fulfil an important social function, giving the group a sense of legitimacy. ${ }^{34}$ Usually, a blot involves a shrine with wooden figures of gods, a goblet of mead, a branch dipped in the mead and sprinkling over guests and gods. ${ }^{35}$ A more detailed performance is presented on the homepage and includes several steps. First participants choose a place and decorate it. Then the start of the blot can be marked in several ways, either by a blow in a horn, a song, or another sound. The dedication of the place occurs by circling it with fire or rattling keys, or presenting the gifts, or making the sign of the hammer. The atmosphere settles in by means of singing, sharing mead, splashing water, after which peace is declared. This is done by grasping each other's hands or swearing on oath rings. Specific entities are invited to join by reciting fragments of old poems that would attest their power. Besides the invocations and offerings, participants can also engage in a magic show, meaning a theatre play, a story based on a myth, a meditation or anything of

\footnotetext{
${ }^{33}$ samfundetfornsed.se/blot/blot-och-högtider, accessed 21.04.2021

${ }^{34}$ Gregorius, 246

${ }^{35}$ Strmiska (ed.), 130
} 
the sort. Participants bring a personal offering to the shrine, perhaps the most religious part of the whole ritual. ${ }^{36}$ Toasting in a circle and either keeping silent or summoning a power of choice brings the blot towards the end, concluded with a thank you or final signal, and then participants feast together. These are the general guidelines, gathered in a collection called Högtider och Blot ${ }^{37}$, yet the texts to be read or the other artistic activities to be performed can vary greatly. Some elements, such as the preparation and sharing of lussebullar during julblot, provide a connection to mainstream tradition. The little information on this celebration, mostly from foreign accounts and disparate centuries, partially offers a pillar of faith to hold on to. Dietmar of Merseburg writes of large-scale human and animal sacrifices, while Procopios mentions dark forces in motion and Odin's assistance of the dead to get to their former homes. ${ }^{38}$ Old customs like making promises for the future at this time of the year, on the other hand, turn out to have preserved their meaning. Organising a blot as a fertility ritual for good harvest would also be meaningful had society not evolved out of its agrarian background. In the end, Heathenry gets caught between a more or less romanticised past it is fond of and its potential significance for present times.

Forn Sed Sverige, like its Icelandic counterpart, deals with weddings and other rites of passage in a personalised manner: "Samfundet har utbildade godar och gydjor som kan anlitas som officianter vid olika livsstegsriter. Då ingår förutom själva riten även ett förberedande samtal där livsstegsriten utformas och planeras. En livsstegsrit som utförs av samfundet utgår från vissa hedniska kärnpunkter men stor hänsyn tas också till deltagarnas personliga önskemål." 39 - The society has trained priests and priestesses who can be hired to perform different rites of passage. Besides the rite in itself this also includes a preparatory discussion to conceive and plan the rite. A rite of passage conducted by our association stems from certain heathen core elements but we greatly take into consideration the

\footnotetext{
${ }^{36}$ Gregorius, 258

${ }^{37}$ Gregorius, 227

${ }^{38}$ Britt-Mari Näsström, Blot. Tro och offer i det förkristna Norden (Stockholm: Nordsteds förlag, 2002), 157-158

${ }^{39}$ samfundetfornsed.se/livsteg, accessed 25.04.2021
} 
participants' personal wishes. The statement consists one more argument for the fact that historical references can only represent a very vague starting point and overall the ceremony is an example of religious imagination, which makes the term "eclectic" more suitable than "reconstructionist" to describe the phenomenon. Well aware of Sweden's established position as a secular country and that the small group's rejection of Christianity and interest for a Norse revival might be met with scepticism or exotic curiosity, members point out the significance of internal cohesion and sense of safety, so that the old customs can develop and live on. The old customs, in oter words, do not represent a fixed and well-defined concept to be recovered from the past and set into motion, but an opportunity to actively engage with the past and produce new forms of spirituality. "Vi är en länk från dåtiden till framtiden. För att det ska fungera, för att seden faktiskt ska leva vidare och samfundet vara en riktigt kraft i samhället, så måste alla medlemmar känna sig trygga hos oss." 40 - We are a link of the past to the present. So that it can work, so that the custom can live on and the association can be a force in society, all members should feel safe with us. The other attractive pillar of the organisation constitutes ecology and environmental awareness, alongside the attempt to weaken the consumerist model and promote more constructive involvement with climate change. In Heathenry the myth of Ragnarök is often quoted as a sign for impending doom unless nature once again becomes a resource for wisdom and force.

Regarding the other problematic trend, namely the revival of the farright and its attempts to confiscate Norse symbols, the group now often includes a reciting at the beginning of the blot where groups who politically instrument heathenry are condemned ${ }^{41}$. They have also encouraged the use of symbols like Thor's hammer at gay prides, in order to reverse its misuse. One spokesperson of the Forn Sed, Per Lundberg, has drawn attention that symbols are empty in themselves, yet the more positive connotation his society has worked on to achieve is once more endangered not only by fringe neo-Nazi groups like the Nordic Resistance Movement that employs the tyr

\footnotetext{
${ }^{40}$ I trygghet tillsammans växer seden, 13.08.2020, samfundetfornsed.se/resurser/blogg -8956591

${ }^{41}$ Gregorius, 232
} 
rune, but also competing heathen groups which have a more ethnic approach, like the 2014 founded Asa Community. Forn Sed now requires from its members a stated commitment against racial discrimination." 42 One more point that speaks for the contemporary relevance of both Ford Sed and Heathenry in general refers to gender roles, and how these groups enable feminine empowerment, with priestesses or members very actively involved in the community.

Similar to the Icelandic case, the struggle against and weak point for extremist strains have their roots not only in the general history of the reception of Norse myth and the Viking age, ideologically painted in the $19^{\text {th }}$ and $20^{\text {th }}$ century, but also in local origins. In Sweden too there were attempts in the 70s at establishing groups of Nordic revival, with an ethnicist touch: Breidablik-Gildet in 1975, whose founder Arne Sjöberg was involved in the life reform movement and patterned an order with a cultural an nationalist orientation bringing it closer to right-wing milieus, resulting in controversies with the neo-shamanic network Yggdrassil which later inspired Swedish heathenry and its version of seið. ${ }^{43}$ In 1994 Sveriges Asatrusamfund was founded, with roots not only in neo-shamanism but also the reenactment association Järnåldersföreningen Birka, with arounc 150 members in 1996 and a journal, Mimirs Källa. Following some financial and leadership problems, members joined either a network of ritual groups (Nätverket Forn Sed) or Norrona Samfundet, a group accused of genealogical interpretations of Heathenry. Atfer the reorganisation and renaming of the Asatrusamfund into Samfundet Forn Sed, and its recognition as a religious association, in order to gain respectability and value the association overtly and clearly rejects any xenophobic interpretation of Norse myth. ${ }^{44}$ However, the parallel development of political racial-religious groups such as the Allgermanic Heathen Front, with their latching onto Viking imagery, still raises difficult questions about the potential common ground or unwanted interactions of

\footnotetext{
${ }^{42} \mathrm{H}$. Libell \& R. Hemphill, As fringe groups adopt Viking symbols, Nordic unease is enough to sink a ship, seattletimes.com/nation-world/as-fringe-groups-adopt-viking-symbols-nordicunease-is-enough-to-sink-a-ship

${ }^{43}$ Von Schnurbein, 61

${ }^{44}$ Von Schnurbein, 62
} 
the movements which for various reasons deal with Nordic revival. The emptiness of the symbols can also be called into question due to their rich history of völkisch appropriation which continue to leave them vulnerable.

From this short presentation of the two Heathen organisations we can draw some conclusions that might be a starting point for further research. First of all, we could notice the flexible approach to myth and ritual, because members share the possibility to interpret the old ways at will and choose what they consider relevant. Therefore, we can infer the higher significance of lived spirituality and direct connection with otherworldly forces than endless discussions on authenticity and historicity. In the same time, the eclectic nature of the phenomenon determines us to classify Heathenry as new religious trends rooted in postmodern fluidity that includes the fascination for the past as a basis for meaning and sense of belonging.

Secondly, each heathen group should be tackled in particular when identifying their relationship to the contemporary framework and its new challenges. Reimagining the past and employing it as a source of spirituality has been more than often regarded suspiciously due to the unfortunate ties of the subject matter to nationalistic or extremist milieus. Nowadays, also given the growing popularity of the Viking age due to a broad range of cultural products, the fascination with this part of history and adoption of Norse symbols in many different ways give birth to further tension and debates with regard to the context and purpose of their usage. That Viking symbols and Norse myths can appeal to such a broad spectre of people confirms the lack of information on the topic and how easily it can be twisted. On the other hand, the very lack of dogma inside Heathenry could cause downfalls precisely because individual belief and practice represents a fertile ground for any kind of approach, including those which groups like Ásatrúarfélagið or Forn Sed speak against. The image that these two groups present, at least, tends to go beyond the ethnicist view towards a more liberal and inclusive one, yet more field work would be needed in order to see how members or sympathizers actually form and live their religiousness and how they define Heathenry. Every heathen group should be contextualized more 
broadly, as our cases from Iceland and Sweden reveal a strong connection with more general societal values.

\section{Bibliography}

\section{Literature}

Blain, Jenny. Researching Paganism. Oxford: AltaMira Press, 2004.

Byock, Jesse. Viking age Iceland. London: Penguin Books, 2001.

Graichen, Gisela. Die neuen Hexen. Goldmann Wilhelm GmbH, 1999.

Gardell, Matthias. Gods of the Blood. Durham: Duke University Press Books, 2003.

Gregorius, Frederik. Modern Asatru. Att konstruera etnisk och kulturell identitet. Lunds universitet: Media-Tryck, 2009.

Näsström, Britt-Mari. Blot. Tro och offer $i$ det förkristna Norden. Stockholm: Nordsteds förlag, 2002.

Stefanie von Schnurbein. Norse Revival. Transformations of Germanic Neopaganism. Boston: Brill, 2016.

Schurack, Silke. Burial practice in contemporary Iceland. Tradition and conflict. Háskoli Islands: 2014.

Skott, Fredrik. Asatro i tiden. Göteborg: Språk- och folkminnesinstitutet, 2000.

Snook, Jennifer. American heathens: the politics of identity in a Pagan religious movement: a sociological ethnography of American Asatru. Pennsylvania: Temple University Press, 2015.

Steinsland, Gro. Fornnordisk religion. Stockholm: Natur och Kultur, 2007.

Strmiska, Michael (ed.). Modern Paganism in World Cultures. Santa Barbara: ABC CLIO, 2005.

Strmiska, Michael. "Ásatrú in Iceland. The rebirth of Nordic Paganism?". In Nova Religio, The Journal of Alternative and Emergent Religions 4:1. University of California Press, 2000.

Zernack, Julia. “Germanische Altertumskunde, Skandinavistik und vöklische Religiosität". In Völkische Religiosität und Krisen der Moderne. Entwürfe "arteigener" Glaubenssysteme seit der 
Jahrhundertwende. Eds. J. Ulbricht, S. von Schnurbein. Würzburg, 2001.

\section{Internet resources}

asatru.is, accessed 20.04.2021 - 25.04.2021

samfundetfornsed.se, accessed 20.04.2021 - 25.04.2021

visir.is, accessed 20.04.2021 - 25.04.2021

Magnus.jennsson.is, accessed 20.04.2021 - 25.04.2021

mbl.is, accessed 20.04.2021 - 25.04.2021

weforum.org, accessed 20.04.2021 - 25.04.2021

bbc.com, accessed 20.04.2021 - 25.04.2021

seattletimes.com, accessed 20.04.2021 - 25.04.2021 